Website: https://journal.stiba.ac.id

ISSN : 2685-7537 (online); 2338-5251 (Printed)

\title{
PENGARUH PENGGUNAAN MEDIA PEMBELAJARAN ZOOM \\ TERHADAP HASIL BELAJAR FIKIH \\ MAHASISWA JURUSAN SYARIAH SEMESTER V \\ STIBA MAKASSAR
}

\section{THE EFFECT OF THE USE OF ZOOM LEARNING MEDIA ON FIQH LEARNING OUTCOMES OF STUDENTS OF SHARIA DEPARTMENT IN FIFTH SEMESTER AT STIBA MAKASSAR}

\author{
Hamudin P. \\ Sekolah Tinggi Ilmu Islam dan Bahasa Arab (STIBA) Makassar \\ Email: hamuddin@stiba.ac.id \\ Sulaiman Saat \\ Universitas Islam Negeri (UIN) Alauddin Makassar \\ Email: sittimania@yahoo.com \\ Sitti Mania \\ Universitas Islam Negeri (UIN) Alauddin Makassar \\ Email: sulaimansaat@yahoo.co.id
}

\section{Keywords: \\ zoom learning media, learning} motivation, learning outcomes
This study aims to describe the use of zoom learning media, learning motivation, and fiqh learning outcomes, as well as to analyze the effect of using zoom learning media and learning motivation on fiqh learning outcomes of students of Sharia Department in Fifth Semester at STIBA Makassar, either partially or simultaneously. The type of research in this research is ex post facto that analyzed by descriptive and inferential statistics. The results of study showed that: 1) The use of zoom learning media is in the good enough category. 2) Learning motivation is in the good enough category. 3) Jurisprudence learning outcomes are in the high category. 4) There is an effect of using zoom learning media on fiqh learning outcomes, the effect is $28.4 \%$. This means that in this study $28.4 \%$ of the variables of fiqh learning outcomes were influenced by the variable of using zoom learning media and included in the weak but definite category. 5) There is an influence of learning motivation on figh learning outcomes, the effect is $17.6 \%$. This means that in this study $17.6 \%$ of the fiqh learning outcomes variables were influenced by learning motivation variables and included in the very weak category. 6) There is an effect of using zoom learning media and learning motivation on figh learning outcomes for students at STIBA Makassar, the effect is $8.8 \%$. This means that in this study $8.8 \%$ of the variables of fiqh learning outcomes were influenced by the variable use of zoom learning media and learning motivation variables together and included in the very weak category, the rest was influenced by other factors not examined in this study.

Kata kunci:
media pembelajaran zoom,
motivasi belajar, hasil belajar
ABSTRAK

Penelitian ini bertujuan untuk mengetahui gambaran penggunaan media pembelajaran zoom, motivasi belajar, dan hasil belajar fikih, serta menganalisis pengaruh penggunaan media pembelajaran zoom dan motivasi belajar terhadap hasil belajar fikih Mahasiswa Jurusan Syariah Semester V Prodi Perbandingan Mazhab STIBA Makassar, 


\begin{abstract}
baik secara parsial maupun simultan. Jenis penelitian ini adalah penelitian ex post facto dengan Teknik statistik deskriptif dan inferensial. Hasil penelitian menunjukkan bahwa: 1) Penggunaan media pembelajaran zoom berada pada kategori cukup baik. 2) Motivasi belajar berada pada kategori cukup baik. 3) Hasil belajar fikih berada pada kategori tinggi. 4) Terdapat pengaruh penggunaan media pembelajaran zoom terhadap hasil belajar fikih, pengaruhnya sebesar $28,4 \%$. Artinya bahwa dalam penelitian ini $28,4 \%$ variabel hasil belajar fikih dipengaruhi oleh variabel penggunaan media pembelajaran zoom dan termasuk kategori lemah tapi pasti. 5) Terdapat pengaruh motivasi belajar terhadap hasil belajar fikih, pengaruhnya sebesar $17,6 \%$. Artinya bahwa bahwa dalam penelitian ini $17,6 \%$ variabel hasil belajar fikih dipengaruhi oleh variabel motivasi belajar dan termasuk kategori yang sangat lemah. 6) Terdapat pengaruh penggunaan media pembelajaran zoom dan motivasi belajar terhadap hasil belajar fikih pada Mahasiswa Jurusan Syariah Semester V Prodi Perbandingan Mazhab STIBA Makassar, pengaruhnya sebesar $8,8 \%$. Artinya bahwa dalam penelitian ini $8,8 \%$ variabel hasil belajar fikih dipengaruhi oleh variabel penggunaan media pembelajaran zoom dan variabel motivasi belajar secara bersamasama dan termasuk kategori yang sangat lemah, selebihnya dipengaruhi oleh faktor lain yang tidak diteliti dalam penelitian ini.
\end{abstract}

Diterima: 26 Oktober 2021; Direvisi: 9 Desember 2021; Disetujui: 9 Desember 2021 Tersedia online: 10 Desember 2021

How to cite: Hamuddin P., Sulaiman Saat, Sitti Mania, "Pengaruh Penggunaan Media Pembelajaran Zoom terhadap Hasil Belajar Fikih Mahasiswa Jurusan Syariah Semester V STIBA Makassar", NUKHBATUL 'ULUM: Jurnal Bidang Kajian Islam Vol. 7, No. 2 (2021): 279-297. doi: 10.36701/nukhbah.v7i2.443.

\title{
PENDAHULUAN
}

Awal tahun 2020, dunia digemparkan dengan merebaknya virus baru yaitu coronavirus jenis baru (SARS-CoV-2) dan penyakitnya disebut coronavirus disease 2019 (COVID-19). Diketahui, asal mula virus ini berasal dari Wuhan, Tiongkok, yang ditemukan pada akhir Desember tahun 2019 dan menyebar ke beberapa negara di dunia termasuk Indonesia. Di Indonesia, pasien terkonfirmasi Covid-19 berawal dari suatu acara di Jakarta yang melakukan kontak dengan seorang Warga Negara Asing (WNA) asal Jepang yang tinggal di Malaysia. ${ }^{1}$ Kejadian tersebut mengakibatkan pemerintah Indonesia menghimbau masyarakat untuk tetap berada di dalam rumah dan melakukan aktivitas bekerja dan belajar dari rumah. Selain itu, pemerintah juga menerapkan aturan Pembatasan Sosial Berskala Besar (PSBB) yakni membatasi kegiatan di luar rumah termasuk aktivitas dalam bidang pendidikan.

Pemerintah telah mengambil kebijakan khusus terkait pelaksanaan pembelajaran di seluruh jenjang pendidikan. Pembelajaran harus dilaksanakan dengan skenario yang mampu mencengah terjadinya kontak fisik baik antara dosen dengan mahasiswa maupun mahasiswa dengan mahasiswa. Aktivitas pendidikan yang

${ }^{1}$ Yuliana Yuliana, "Corona Virus Diseases (Covid-19): Sebuah Tinjauan Literatur," Wellness And Healthy Magazine 2, no. 1 (2020): 187-192. 
biasanya dilakukan dengan tatap muka dialihkan kepada pembelajaran berbasis daring (jarak jauh) dengan memanfaatkan teknologi yang terhubung dengan internet. Pembelajaran daring merupakan pembelajaran yang menggunakan jaringan internet dengan aksesibilitas, konektivitas, fleksibilitas, dan kemampuan untuk memunculkan berbagai jenis interaksi pembelajaran. ${ }^{2}$ Pelaksanaan pembelajaran daring memungkinkan dosen dan mahasiswa melaksanakan perkuliahan dari rumah. Tindakan ini bisa mengurangi timbulnya kerumunan mahasiswa di kampus seperti yang terjadi pada perkuliahan tatap muka.

Hasil wawancara via telepon dengan salah satu dosen prodi Perbandingan Mazhab Sekolah Tinggi Ilmu Islam dan Bahasa Arab (STIBA) Makassar mengatakan bahwa hasil belajar mahasiswa menurun selama pandemik. Hal ini terjadi karena tidak adanya tatap muka antara dosen dan mahasiswa di dalam kelas, sehingga dosen tidak bisa mengontrol kegiatan dan menjaga suasana belajar mahasiswa secara penuh. Selain itu, beberapa mahasiswa sering terlambat mengirim tugas. Mereka lebih banyak menghabiskan waktu untuk bermain media sosial dan game online. ${ }^{3}$ Adapun hasil wawancara dengan salah satu mahasiswa menyatakan bahwa mereka mengeluh bosan dengan metode pembelajaran yang monoton. Dosen hanya memberikan materi Power Point di grup WhatsApp lalu menyuruh mereka mengerjakan tugas-tugas. Hal inilah yang membuat mereka menjadi jenuh karena dalam pembelajaran tatap muka saja, mereka masih banyak yang bingung dan bertanya berulang-ulang apalagi jika hanya melalui grup WhatsApp. ${ }^{4}$ Kondisi pembelajaran daring juga menyebabkan dosen kesulitan untuk mengontrol dan menjaga suasana belajar karena keterbatasan dalam ruang virtual. Kondisi ini menyebabkan motivasi belajar mahasiswa dapat menurun bahkan mempengaruhi hasil belajar mahasiswa.

Kurangnya motivasi belajar menyebabkan mahasiswa menjadi kurang aktif dalam penyampaian pendapat dan pemikirannya, sehingga mengakibatka proses belajar yang membosankan. Oleh karena itu, diperlukan pendorong untuk menggerakkan mahasiswa agar lebih semangat belajar sehingga dapat memiliki prestasi belajar. Salah satunya dengan menggunakan media pembelajaran zoom cloud meeting Pemilihan media pembelajaran yang tepat dan dukungan berbagai pihak sangat menentukan keberhasilan pembelajaran online yang tentunya berdampak positif pada hasil belajar mahasiswa. Pemilihan media pembelajaran zoom cloud meeting sebagai media pembelajaran daring pada masa pandemik COVID-19 didasari pada pertimbangan bahwa zoom cloud meeting memiliki cukup banyak kelebihan, di antaranya dosen dan mahasiswa dapat berinteraksi langsung meskipun dengan jarak yang berjauhan. Hal senada dinyatakan oleh Muhammad Harun bahwa zoom cloud meeting memiliki cukup banyak kelebihan, di antaranya memiliki fitur video conferencing kualitas HD, online meeting, chatting, mendukung hingga 1000 peserta, rekaman, dan penjadwalan meeting. ${ }^{5}$ Pembelajaran dengan menggunakan media zoom

${ }^{2}$ Ali Sadikin and Afreni Hamidah, "Pembelajaran Daring Di Tengah Wabah Covid-19 (Online Learning in the Middle of the Covid-19 Pandemic)," Biodik 6, no. 2 (2020): 214-224.

${ }^{3}$ Baharuddin (41 tahun), Dosen STIBA Makassar, Wawancara, Makassar, 26 Agustus 2020.

${ }^{4}$ Nur Hikmah (21 tahun). Mahasiswi Jurusan Syariah Prodi Perbandingan Mazhab STIBA Makassar. Wawancara. Makassar, 04 Januari 2021.

${ }^{5}$ Muhamad Harun, "Evaluasi Kualitas Perangkat Lunak Pada Aplikasi Zoom Cloud Meetings Untuk Pembelajaran Elearning," Jurnal Akrab Juara 5, no. 3 (2020): 102-112. 
cloud meeting ini diharapkan menciptakan suasana yang kondusif untuk belajar secara kreatif dan inovatif. Selain itu, proses pembelajaran akan mencapai keberhasilan apabila peserta didik memiliki motivasi belajar yang baik. ${ }^{6}$

Zoom cloud meeting merupakan platform tatap muka yang bersifat conference dimana pendidik dan peserta didik bisa langsung berinteraksi selayaknya bertemu langsung. Aplikasi ini menyediakan banyak fitur mulai dari file sharing dalam format $P D F$ yang bisa dilakukan dengan mudah, individu yang mau bergabung dengan conference/meeting hanya dengan tautan atau nomor kamar, zoom synchronous online formats juga meliputi two-way live broadcast lectures. Zoom menjadikan kursus online menjadi sangat populer karena menghemat biaya waktu perjalanan, biaya bahan bakar, dan dampaknya terhadap lingkungan. Zoom memiliki biaya finansial yang rendah dan menawarkan pengalaman webinar yang bagus. ${ }^{7}$ Media zoom cloud meeting merupakan aplikasi yang digunakan sebagai media komunikasi jarak jauh dengan menggabungkan konferensi video, obrolan, pertemuan online, dan kolaborasi seluler. ${ }^{8}$ Jadi, aplikasi zoom merupakan salah satu media komunikasi yang memungkinkan dua orang atau lebih melakukan pertemuan dengan memanfaatkan jaringan internet.

Kelebihan penggunaan zoom dibandingkan dengan penggunaan WhatsApp Group dalam pembelajaran di dalam kelas virtual antara dosen dan mahasiswa diungkapkan oleh Wijaya Kusuma dan Hamidah antara lain sebagai berikut: 1) Mahasiswa lebih mudah memahami materi karena dosen menjelaskan secara langsung materi yang disampaikan; 2) Mahasiwa dapat bertanya dan berdiskusi secara leluasa seperti perkuliahan di kelas; 3) Pertanyaan mahasiswa dapat direspon langsung sehingga lebih efektif; 4) Mahasiswa tidak merasa bosan dengan materi yang disampaikan karena tatap muka langsung; dan 5) Keaktifan mahasiswa dapat dipantau sehingga mendorong mahasiswa lebih fokus. Kelemahan penggunaan zoom dalam pembelajaran kelas virtual antara dosen dan mahasiswa diungkapkan oleh Wijaya Kusuma dan Hamidah antara lain sebagai berikut: 1) Mahasiswa yang berada pada lokasi dengan kekuatan sinyal tidak stabil, mengeluhkan untuk bergabung maupun mengikuti proses pembelajaran yang berlangsung; 2) Tidak sedikit mahasiswa yang mengeluhkan borosnya kuota; 3) Tidak bisa mengulang materi yang telah disampaikan. ${ }^{9}$

Motivasi berasal dari bahasa Latin movere yang artinya "menggerakkan '(to move). ${ }^{10}$ Motivasi adalah suatu tindakan yang menggerakkan dan memilih untuk

${ }^{6}$ Adhetya Cahyani, Iin Diah Listiana, and Sari Puteri Deta Larasati, "Motivasi Belajar Siswa SMA Pada Pembelajaran Daring Di Masa Pandemi Covid-19," IQ (Ilmu Al-Qur'an): Jurnal Pendidikan Islam 3, no. 01 (2020): 123-140.

${ }^{7}$ Ahmad Chusyairi and Sahla Sabira, "Pelatihan Pembuatan Konten Pendidikan Pada YouTube Menggunakan Zoom Dan Editing Video Filmora," JILPENMAS (Jurnal Ilmiah Pengabdian Masyarakat) 1, no. 01 (2020): 55-65.

${ }^{8}$ Dwi Ismawati and Iis Prasetyo, "Efektivitas Pembelajaran Menggunakan Video Zoom Cloud Meeting Pada Anak Usia Dini Era Pandemi Covid-19," Jurnal Obsesi: Jurnal Pendidikan Anak Usia Dini 5, no. 1 (2020): 665-75.

${ }^{9}$ Eko Yulianto, Putri Dwi Cahyani, and Sofia Silvianita, "Perbandingan Kehadiran Sosial Dalam Pembelajaran Daring Menggunakan Whatsapp Groupdan Webinar Zoom Berdasarkan Sudut Pandang Pembelajar Pada Masa Pandemic COVID-19," Jurnal Riset Teknologi Dan Inovasi Pendidikan (JARTIKA) 3, no. 2 (2020): 331-341.

${ }^{10}$ Winard, Motivasi Dan Permotivasian Dalam Manajemen (Jakarta: Raja Grafindo Persada, 2011). h. 24 . 
melakukan suatu perbuatan ke arah tujuan yang akan dicapai. ${ }^{11}$ Mc. Donald menyatakan bahwa motivation is an energy change within the person characterized by affective arousal and anticipatory goal reaction. Motivasi adalah perubahan energi dalam diri pribadi seseorang yang ditandai dengan timbulnya perasaan reaksi untuk mencapai tujuan. ${ }^{12}$ Motivasi merupakan proses internal yang mengaktifkan dan memandu serta memelihara perilaku seseorang secara terus menerus. Sumber utama munculnya motif adalah rangsangan (stimulus) situasi sekarang dengan situasi yang akan diharapkan, sehingga tanda perubahan tersebut tampak pada adanya perbedaan afektif saat munculnnya motif dan saat usaha pencapaian yang diharapkan. ${ }^{13}$ Motivasi belajar adalah dorongan internal dan eksternal pada siswa (mahasiswa) yang sedang belajar sehingga mengadakan perubahan tingkah laku, yang mempunyai indikator sebagai berikut: (1) adanya hasrat dan keinginan untuk sukses dan berhasil, (2) adanya dorongan dan kebutuhan dalam belajar, (3) adanya harapan dan cita-cita masa depan, (4) adanya penghargaan dalam kelompok, (5) adanya kegiatan yang menarik dalam belajar, dan (6) adanya lingkungan yang kondusif sehingga siswa (mahasiswa) dapat belajar dengan baik. ${ }^{14}$

Menurut Sardiman, motivasi belajar merupakan faktor psikis yang bersifat nonintelektual dan berperan dalam hal penumbuh gairah, merasa senang, dan semangat untuk belajar. Winkel menambahkan bahwa motivasi belajar memegang peranan penting dalam memberikan gairah atau semangat dalam belajar sehingga siswa (mahasiswa) yang bermotivasi kuat memiliki energi banyak untuk melakukan kegiatan belajar. Salah satu indikator keberhasilan pendidikan secara mikro ditataran pembelajaran kelas adalah tatkala seorang guru mampu membangun motivasi belajar siswa (mahasiswanya). Jika siswa-siswa (mahasiswa-mahasiswa) tersebut dapat ditumbuhkembangkan motivasi belajarnya, maka sesulit apapun materi pelajaran atau proses pembelajaran yang mereka jalani niscaya mereka akan menjalaninya dengan sangat menyenangkan. ${ }^{15}$ Salah satu teori yang terkenal kegunaannya untuk menerangkan motivasi siswa (mahasiswa) adalah toeri yang dikembangkan oleh Maslow.

Maslow percaya bahwa tingkah laku manusia dibangkitkan dan diarahkan oleh kebutuhan-kebutuhan tertentu. Kebutuhan-kebutuhan tersebut dibagi oleh Maslow ke dalam tujuh kategori yakni: (1) Fisiologis; (2) Rasa aman; (3) Rasa cinta; (4) Penghargaan; (5) Aktualisasi diri; (6) Mengetahui dan mengerti; dan (7) Kebutuhan estetik. ${ }^{16}$ Selain itu, terdapat model motivasi ARCS (Attention, Relevance, Confidence, Satisfaction) yang dikembangkan oleh Keller dan Kopp sebagai jawaban pertanyaan bagaimana merancag pembelajaran yang dapat memengaruhi motivasi dan hasil

\footnotetext{
${ }^{11}$ Martini Jamaris, “Orientasi Baru Dalam Psikologi Pendidikan,” (Bogor: Ghalia Indonesia, 2013). h. 170

${ }^{12}$ Oemar Hamalik, Proses Belajar Mengajar (Jakarta: Bumi Aksara, 2012). h. 158.

${ }^{13}$ Achmad Rifa'i Rc and Catharina Tri Anni, "Psikologi Pendidikan" (Semarang: Pusat Pengembangan MKU \&MKDK Universitas Negeri Semarang, 2011). h.159.

${ }^{14}$ B Uno Hamzah, "Teori Motivasi Dan Pengukurannya," (Jakarta: Bumi Aksara, 2011). h.10.

${ }^{15}$ Mohamad Syarif Sumantri, "Strategi Pembelajaran Teori Dan Praktik Di Tingkat Pendidikan Dasar," (Jakarta: Rajawali Pers, 2015). h. 379.

${ }^{16}$ Muh Yusuf Mappeasse, "Pengaruh Cara Dan Motivasi Belajar Terhadap Hasil Belajar Programmable Logic Controller (PLC) Siswa Kelas III Jurusan Listrik SMK Negeri 5 Makassar," Jurnal Medtek 1, no. 2 (2009): 1-6.
} 
belajar. Model ini dikembangkan berdasarkan teori nilai harapan (expectancy value theory) yang mengandung dua komponen yaitu nilai (value) dari tujuan yang akan dicapai dan harapan (expectancy) agar berhasil mencapai tujuan tersebut. Kedua komponen tersebut dikembangkan oleh Keller menjadi empat komponen. Keempat komponen tersebut adalah attention (minat/perhatian), relevance (relevansi), confidence (percaya diri/yakin), dan satisfaction (kepuasan/bangga) dengan akronim ARCS dan menjadi empat kategori yang mewakili bermacam karakteristik motivasi yang ada dalam setiap individu. ${ }^{17}$ Molace dalam Ani Asiani, dkk., menyatakn bahwa ARCS adalah hasil dari studi literatur penelitian tentang motivasi dan juga praktek sukses dan telah divalidasi melalui beberapa studi, tujuan dari model ini adalah membantu peserta didik/mahasiswa untuk mendapatkan rasa puas agar peserta didik/mahasiswa terdorong untuk selalu belajar. ${ }^{18}$

Beberapa unsur yang memengaruhi motivasi belajar antara lain sebagai berikut: 1) Cita-cita dan aspirasi siswa (mahasiswa). Cita-cita akan memperkuat motivasi belajar siswa (mahasiswa) baik intrinsik maupun ekstrinsik; 2) Kemampuan siswa (mahasiswa). Keinginan seorang anak perlu dibarengi dengan kemampuan atau kecakapan dalam pencapaiannya; 3) Kondisi siswa (mahasiswa). Kondisi siswa (mahasiswa) yang meliputi kondisi jasmani dan rohani memengaruhi motivasi belajar; 4) Kondisi lingkungan siswa (mahasiswa). Lingkungan siswa (mahasiswa) dapat berupa keadaan alam, keadaan tempat tinggal, pergaulan sebaya, dan kehidupan bermasyarakat. ${ }^{19}$

Hasil belajar dapat dijelaskan dengan memahami dua kata yang membentuknya, yaitu "hasil" dan "belajar". Pengertian hasil (product) menunjuk pada suatu perolehan akibat dilakukannya suatu aktivitas atau proses yang mengakibatkan berubahnya input secara fungsional. Hasil dapat dengan jelas dibedakan dengan input akibat perubahan oleh proses dalam suatu siklus input-proses-hasil. Begitu pula dalam kegiatan belajar mengajar, setelah mengalami belajar siswa (mahasiswa) berubah perilakunya dibanding sebelumnya. Belajar dilakukan untuk mengusahakan adanya perubahan perilaku pada individu yang belajar. Perubahan perilaku itu merupakan perolehan yang menjadi hasil belajar. ${ }^{20}$ Belajar adalah suatu proses usaha yang dilakukan seseorang untuk memperoleh suatu perubahan tingkah laku yang baru secara keseluruhan, sebagai hasil pengalamannya sendiri dalam interaksi dengan lingkungannya. ${ }^{21}$ Chaplin membatasi belajar dengan dua macam rumusan. Rumusan pertama yakni ... acquisition of any relatively permanent change in behavior as a result of practice and experience. Belajar adalah perolehan perubahan tingkah laku yang

${ }^{17}$ Mekka Madaina Jamil, “Optimalisasi Model ARCS Dalam Pembelajaran Saintifik Untuk Meningkatkan Motivasi Belajar Peserta Didik Pada Peminatan Mata Pelajaran Geografi Di Kelas Matematika Ilmu Alam," IJIS Edu: Indonesian Journal of Integrated Science Education 1, no. 1 (2019): $7-24$.

${ }^{18}$ Ani Asiani and Jonet Ariyanto Nugroho, "Penerapan Model Attention, Relevance, Confidence, And Satisfaction (Arcs) Untuk Meningkatkan Motivasi Dan Hasil Belajar Siswa Kelas X Pemasaran 1 Smk Negeri 1 Surakarta Tahun Pelajaran 2016/2017," Jurnal Pendidikan Bisnis Dan Ekonomi 3, no. 1 (2017).

${ }^{19}$ Mudjiono Dimyati, “Belajar Dan Pembelajaran,”( Jakarta: Rineka Cipta, 2006). h.96.

${ }^{20}$ Purwanto, Evaluasi Hasil Belajar, 3rd ed. (Yogyakarta: Pustaka Pelajar, 2011). h. 44-45.

${ }^{21}$ Slameto, Belajar Dan Faktor-Faktor Yang Mempengaruhinya (Jakarta: Rineka Cipta, 2010). h.2. 
relatif menetap sebagai akibat latihan dan pengalaman. Rumusan kedua yakni process of acquiring responses as a result of special practice. Belajar adalah proses memeroleh respon-respon sebagai akibat adanya latihan khusus. ${ }^{22}$

Menurut Slameto, keberhasilan seorang siswa (mahasiswa) dalam belajar dipengaruhi oleh dua faktor yaitu faktor intern dan faktor ekstern. Faktor intern merupakan faktor yang berasal dari dalam diri seorang siswa (mahasiswa). Faktor intern meliputi faktor jasmaniah dan faktor psikologis. Faktor jasmaniah meliputi kesehatan dan cacat tubuh. Faktor psikologis meliputi intelegensi, perhatian, minat, bakat, motif, kematangan, kesiapan, dan keaktifan siswa (mahasiswa) dalam bermasyarakat. Faktor ekstern meliputi faktor keluarga, faktor sekolah, dan faktor masyarakat. Faktor keluarga meliputi cara orang tua mendidik, relasi antara anggota keluarga, suasana rumah tangga, keadaan ekonomi keluarga, pengertian orang tua, dan latar belakang kebudayaan. Faktor sekolah meliputi metode mengajar, kurikulum, hubungan guru dengan siswa (mahasiswa), hubungan siswa (mahasiswa) dengan siswa (mahasiswa), disiplin sekolah, alat pelajaran, waktu sekolah, standar pelajaran di atas ukuran, keadaan gedung, metode belajar, dan tugas rumah. Faktor masyarakat meliputi kegiatan siswa (mahasiswa) dalam masyarakat, media massa, teman bergaul, dan bentuk kehidupan masyarakat. ${ }^{23}$

Berdasarkan uraian di atas, permasalahan penelitian ini dirumuskan sebagai berikut: (1) Bagaimana penggunaan media pembelajaran zoom pada pembelajaran fikih Mahasiswa Jurusan Syariah Semester V Prodi Perbandingan Mazhab STIBA Makassar?; (2) Bagaimana motivasi belajar Mahasiswa Jurusan Syariah Semester V Prodi Perbandingan Mazhab STIBA Makassar; (3) Bagaimana hasil belajar fikih Mahasiswa Jurusan Syariah Semester V Prodi Perbandingan Mazhab STIBA Makassar; (4) Seberapa besar pengaruh penggunaan media pembelajaran zoom terhadap hasil belajar fikih Mahasiswa Jurusan Syariah Semester V Prodi Perbandingan Mazhab STIBA Makassar; (5) Seberapa besar pengaruh motivasi belajar terhadap hasil belajar fikih Mahasiswa Jurusan Syariah Semester V Prodi Perbandingan Mazhab STIBA Makassar; dan (6) Seberapa besar pengaruh penggunaan media pembelajaran zoom dan motivasi belajar secara bersama-sama terhadap hasil belajar fikih Mahasiswa Jurusan Syariah Semester V Prodi Perbandingan Mazhab STIBA Makassar.

Tujuan penelitian adalah untuk mengetahui gambaran penggunaan media pembelajaran zoom, motivasi belajar, dan hasil belajar fikih Mahasiswa Jurusan Syariah Semester V Prodi Perbandingan Mazhab STIBA Makassar. Selain itu, penelitian ini juga bertujuan untuk menganalisis pengaruh penggunaan media pembelajaran zoom dan motivasi belajar terhadap hasil belajar fikih Mahasiswa Jurusan Syariah Semester V Prodi Perbandingan Mazhab STIBA Makassar baik secara parsial maupun simultan.

Jenis penelitian yang digunakan dalam penelitian ini adalah penelitian ex post facto. Adapun model desain pada penelitian ini menggunakan paradigma ganda. Paradigma ganda merupakan paradigma penelitian yang terdiri atas dua variabel independen (bebas) yaitu penggunaan media pembelajaran zoom (X1), motivasi

\footnotetext{
${ }^{22}$ Muhibbin Syah, Psikologi Pendidikan Dengan Pendekatan Baru (Bandung: Remaja Rosdakarya, 2010). h. 90.

${ }^{23}$ Slameto, Belajar Dan Faktor-Faktor Yang Mempengaruhinya. h.54.
} 
belajar (X2) dan satu variabel dependen (terikat) yaitu hasil belajar fikih (Y). Penelitian dilakukan di Jurusan Syariah Semester V Prodi Perbandingan Mazhab Sekolah Tinggi Ilmu Bahasa Arab (STIBA) Makassar, Jalan Inspeksi PAM Timur Kelurahan Manggala, Kecamatan Manggala, Kota Makassar, Propinsi Sulawesi Selatan. Populasi dalam penelitian ini adalah seluruh mahasiswa dan dosen Jurusan Syariah Semester V Prodi Perbandingan Mazhab Sekolah Tinggi Ilmu Bahasa Arab (STIBA) Makassar tahun pelajaran 2020/2021 yang melaksanakan pembelajaran menggunakan media pembelajaran via zoom berjumlah 380 orang yang terdiri dari 368 mahasiswa dan 12 dosen. Teknik pengambilan sampel yang digunakan dalam penelitian ini adalah simple random sampling. Sampel dalam penelitian ini berjumlah 184 orang. Teknik pengumpulan data menggunakan angket dan tes. Instrumen yang digunakan dalam penelitian ini adalah angket penggunaan media pembelajaran zoom, angket motivasi belajar, dan tes hasil belajar fikih. Validitas instrumen tes hasil belajar ditempuh dengan uji coba responden, sedangkan validasi instrumen angket penggunaan media pembelajaran dan angket motivasi belajar ditempuh dengan validasi ahli. Validitas atau kesahihan menunjukkan sejauh mana suatu alat ukur mampu mengukur apa yang ingin diukur ( $a$ valid measure if it succesfully measure the phenomenom). ${ }^{24}$ Metode yang digunakan untuk melakukan uji reliabilitas instrumen angket dalam penelitian ini adalah metode alpha cronbach. Metode alpha cronbach merupakan metode yang digunakan untuk menghitung reliabilitas suatu tes yang tidak mempunyai pilihan jawaban "benar" atau "salah" maupun "ya" atau "tidak", melainkan digunakan untuk menghitung reliabilitas suatu tes yang mengukur sikap atau perilaku. ${ }^{25}$ Analisis yang digunakan untuk uji reliabilitas instrumen tes hasil belajar adalah analisis K.R.20. Teknik analisis data yang digunakan dalam penelitian ini adalah analisis statistik deskriptif dan analisis statistik inferensial.

Analisis statistik deskriptif bertujuan untuk memberikan deskripsi mengenai subjek penelitian berdasarkan data dari variabel yang diperoleh dari kelompok subjek yang diteliti dan tidak dimaksudkan untuk pengujian hipotesis. Analisis deskriptif digunakan untuk memeroleh gambaran data penggunaan media pembelajaran, motivasi belajar mahasiswa, dan hasil belajar fikih meliputi skor terendah, skor tertinggi, rata-rata (mean), dan standar deviasi. Deskripsi data penelitian menggunakan kategorisasi penggunaan media pembelajaran, motivasi belajar, dan hasil belajar. Kategorisasi data penggunaan media pembelajaran, motivasi belajar, dan hasil belajar menggunakan cara yaitu dengan membuat kategori, dimana interval (lebar kelas) dari data yang ada dibuat terlebih dahulu dengan menggunakan rumus kategori, bukan rumus interval. Caranya adalah nilai perolehan tertinggi dikurangi dengan nilai terendah dibagi dengan jumlah kategori. Jumlah kategori ditentukan berdasarkan jumlah pilihan (option) pada instrumen pengumpulan data. ${ }^{26}$

Analisis statistik inferensial merupakan teknik statistik yang digunakan untuk menguji hipotesis penelitian dengan cara menganalisis data sampel dan hasilnya diberlakukan untuk populasi. Pengujian hipotesis dalam penelitian ini menggunakan

\footnotetext{
${ }^{24}$ Syofian Siregar, "Statistik Parametrik Untuk Penelitian Kuantitatif," (Cet. III; Jakarta: PT Bumi Aksara, 2015), h. 75.

${ }^{25}$ Syofian Siregar, "Statistik Parametrik Untuk Penelitian Kuantitatif,", h. 89.

${ }^{26}$ Sulaiman Saat and Sitti Mania, "Pengantar Metodologi Penelitian: Panduan Bagi Peneliti Pemula,” (Cet. Kedua; Edisi Revisi; Gowa: Pusaka Almaida, 2020). h.115-116.
} 
uji regresi pada aplikasi SPSS for Windows. Kriteria pengujiannya dengan memperhatikan output olahan data. Apabila sig. $<\alpha=0,05$, maka $\mathrm{H}_{0}$ ditolak, $\mathrm{H}_{1}$ diterima dan jika terjadi sebaliknya sig. $>\alpha=0,05$, maka $\mathrm{H}_{0}$ diterima, $\mathrm{H}_{1}$ ditolak. Namun sebelum dilakukan pengujian hipotesis terlebih dahulu dilakukan uji prasyarat yaitu uji normalitas, uji linearitas, dan uji korelasi. Uji normalitas data dimaksudkan untuk mengetahui apakah data sampel berasal dari populasi berdistribusi normal atau tidak. Data dikatakan berdistribusi normal apabila memenuhi kriteria yang digunakan yakni sig. $\geq \alpha=0,05$. Uji linearitas digunakan untuk memastikan apakah data yang kita miliki sesuai dengan garis linear atau tidak. Data dikatakan linear apabila memenuhi kriteria yang digunakan yakni sig. $\geq \alpha=0,05$. Uji korelasi dimaksudkan untuk mengetahui keeratan hubungan/korelasi antar variabel $\mathrm{X}$ dan variabel $\mathrm{Y}$ dengan nilai $r$ sebagai patokan ${ }^{27}: r=0$; tidak ada korelasi, $0<r \leq 0,20$; korelasi sangat rendah/lemah sekali, 0,20 $<r \leq 0,40$; korelasi rendah/lemah tapi pasti, $0,40<r \leq$ 0,70; korelasi yang cukup berarti, $0,70<r \leq 0,90$; korelasi yang tinggi ; kuat, $0,90<r \leq 1,00$; korelasi sangat tinggi; kuat sekali, dapat diandalkan, $r=1$; korelasi sempurna.

Kajian tentang penggunaan aplikasi zoom dan efektifitasnya dalam proses pembelajaran sudah cukup banyak dilakukan oleh para peneliti, diantaranya: pertama, penelitian yang dilakukan oleh Fitriyani, dkk., dengan judul Penggunaan Aplikasi Zoom Cloud Meeting pada Proses Pembelajaran Online sebagai Solusi di Masa Pandemi Covid 19, menyimpulkan bahwa aplikasi zoom cloud meeting seakan-akan menjadi kelas baru dalam proses pembelajaran dan menjadi solusi agar pembelajaran di sekolah atau perguruan tinggi berjalan dengan semestinya. Persamaan dengan penelitian tersebut dengan penelitian ini terletak pada variabel penggunaan zoom cloud meeting. Perbedaan dengan penelitian ini terletak pada variabel motivasi belajar, variabel hasil belajar, waktu, dan lokasi penelitian.

Kedua, penelitian yang dilakukan oleh Ardian Eko Sajaril, dkk., dengan judul The Student Perspective on the Effectiveness of Media Zoom Meeting in Increasing Knowledge of Thesis Writing at STKIP Muhammadiyah Manokwari yang menyimpulkan bahwa penggunaan media zoom tidak efektif dalam meningkatkan pengetahuan mahasiswa tentang penulisan tesis di STKIP Muhammadiyah Manokwari. Persamaan penelitian tersebut dengan penelitian ini terletak pada variabel penggunaan zoom meeting, sedangkan perbedaan dengan penelitian ini terletak pada variabel motivasi belajar, variabel hasil belajar, lokasi penelitian, dan waktu penelitian. Meskipun hasil penelitian tersebut menunjukkan ketidakefektifan penggunaan zoom meeting, hasil penelitian tersebut dapat dijadikan sebagai sumber referensi dalam melakukan penelitian.

Ketiga, penelitian yang dilakukan oleh Junita Monica dan Dini Fitriawati dengan judul Efektivitas Penggunaan Aplikasi Zoom sebagai Media Pembelajaran Online pada Mahasiswa Saat Pandemi Covid-19, menyimpulkan bahwa pembelajaran online menggunakan aplikasi zoom sudah efektif. Selain itu, pembelajaran secara online mendapat tanggapan sangat baik dari mahasiswa karena pembelajaran yang lebih fleksibel saat menggunakannya. Adanya pembelajaran online menjadikan

\footnotetext{
${ }^{27}$ Ridwan Engkos and Achmad Kuncoro, "Cara Menggunakan Dan Memaknai Path Analysis," (Bandung: Alfabeta, 2012). h.223.
} 
mahasiswa lebih mandiri dan mendorong mahasiswa harus lebih aktif dalam perkuliahan. Banyaknya fitur di dalam zoom menjadikan pembelajaran lebih menarik. Penelitian ini dilakukan di Universitas ARS Bandung dengan menggunakan metode pendekatan penelitian kualitatif yang datanya dikumpulkan melalui wawancara kepada mahasiswa. Persamaan dengan penelitian ini terletak pada variabel penggunaan zoom dalam pembelajaran. Sedangkan perbedaan dengan penelitian ini terletak pada jenis penelitian, lokasi penelitian, dan sampel penelitian.

Dari keseluruhan penelitian yang telah disebutkan di atas, belum ada satu penelitian pun yang secara spesifik mengkaji pengaruh penggunaan media zoom dan pengaruhnya terhadap hasil belajar fikih mahasiswa STIBA Makassar.

\section{PEMBAHASAN}

Hasil analisis statistik deskriptif penggunaan media pembelajaran zoom, motivasi belajar mahasiswa, dan hasil belajar fikih pada pembelajaran fikih Mahasiswa Jurusan Syariah Semester V Prodi Perbandingan Mazhab STIBA Makassar disajikan pada tabel berikut:

Tabel 1

Deskripsi Penggunaan Media Pembelajaran Zoom pada Pembelajaran Fikih Mahasiswa Jurusan Syariah Semester V Prodi Perbandingan Mazhab STIBA

Makassar

\begin{tabular}{ccccc}
\hline No. & Kategori & Interval & Frekuensi & Persentase \\
\hline 1. & Sangat Baik & $79-93$ & 4 & 2,17 \\
2. & Baik & $63-78$ & 69 & 37,50 \\
3. & Cukup Baik & $47-62$ & 100 & 54,35 \\
4. & Tidak Baik & $31-46$ & 11 & 5,98 \\
\hline \multicolumn{5}{c}{ Jumlah } \\
\hline
\end{tabular}

Sumber: Data primer, diolah (2020)

Tabel 2

Deskripsi Motivasi Belajar Mahasiswa Jurusan Syariah Semester V Prodi Perbandingan Mazhab STIBA Makassar

\begin{tabular}{ccccc}
\hline No. & Kategori & Interval & Frekuensi & Persentase \\
\hline 1. & Sangat Baik & $86-94$ & 27 & 14,67 \\
2. & Baik & $77-85$ & 51 & 27,72 \\
3. & Cukup Baik & $68-76$ & 65 & 35,33 \\
4. & Tidak Baik & $59-67$ & 41 & 22,28 \\
\hline \multicolumn{5}{c}{ Jumlah } \\
\hline
\end{tabular}

Sumber: Data primer, diolah (2020)

Tabel 3

Deskripsi Hasil Belajar Fikih Mahasiswa Jurusan Syariah Semester V Prodi Perbandingan Mazhab STIBA Makassar 
Website: https://journal.stiba.ac.id

ISSN : 2685-7537 (online); 2338-5251 (Printed)

\begin{tabular}{ccccc}
\hline No. & Kategori & Interval & Frekuensi & Persentase \\
\hline 1. & Tinggi & $58-90$ & 100 & 54,35 \\
2. & Rendah & $25-57$ & 84 & 45,65 \\
\hline \multicolumn{5}{c}{ Jumlah } \\
\hline
\end{tabular}

Sumber: Data primer, diolah (2020)

Berdasarkan Tabel 1 di atas diperoleh informasi bahwa pada kategori sangat baik dengan interval 79-93 memiliki frekuensi 4 dan persentase $2,17 \%$, artinya bahwa terdapat empat responden dari 184 yang mengisi angket menyatakan bahwa penggunaan media pembelajaran zoom sudah sangat baik. Selain itu, pada kategori baik dengan interval 63-78 memiliki frekuensi 69 dan persentase 37,50\%, artinya bahwa terdapat 69 responden dari 184 yang mengisi angket menyatakan bahwa pengunaan media pembelajaran zoom sudah baik. Selanjutnya, pada kategori cukup baik dengan interval 47-62 memiliki frekuensi 100 dan persentase 54,35\%, artinya bahwa terdapat 100 responden dari 184 yang mengisi angket menyatakan bahwa penggunaan media pembelajaran zoom sudah cukup baik. Sedangkan pada kategori tidak baik dengan interval 31-46 memiliki frekuensi 11 dan persentase 5,98\%, artinya bahwa terdapat 11 responden dari 184 yang mengisi angket menyatakan bahwa penggunaan media pembelajaran zoom tidak baik. Persentase tertinggi nilai penggunaan media pembelajaran zoom pada pembelajaran fikih Mahasiswa Jurusan Syariah Semester V Prodi Perbandingan Mazhab STIBA Makassar adalah 54,35\% dengan frekuensi 100 dan berada pada kategori cukup baik. Berdasarkan hasil analisis data diperoleh informasi bahwa nilai perolehan terendah dari angket penggunaan media pembelajaran zoom adalah 31, nilai perolehan tertinggi dari angket penggunaan media pembelajaran zoom adalah 93. Nilai rata-rata diperoleh 60,4 dengan standar deviasi 9,69. Hal tersebut dapat dimaknai bahwa berdasarkan penggunaan media pembelajaran zoom pada pembelajaran fikih Mahasiswa Jurusan Syariah Semester V Prodi Perbandingan Mazhab STIBA Makassar cukup baik. Hal ini didukung data hasil pengisian angket penggunaan media pembelajaran zoom oleh mahasiswa yang pada umumnya menyatakan bahwa dosen fikih cukup baik dalam memberi kesempatan kepada mahasiswa untuk bertanya pada saat pembelajaran menggunakan zoom berlangsung. Selain itu, berdasarkan angket yang diisi diketahui bahwa umumnya mahasiswa memberikan penilaian yang cukup baik ketika dosen fikih memberikan umpan balik seusai menyampaikan materi pembelajaran menggunakan zoom.

Kehadiran zoom sangat membantu berbagai kegiatan yang membutuhkan tatap muka secara virtual, termasuk kegiatan pembelajaran yang melibatkan dosen dan mahasiswa. Selain itu, cara menggunakan zoom cukup mudah. Hal ini senada dengan temuan Junita Monica yang menyatakan bahwa penggunaan zoom menjadi salah satu alternatif sebagai pembelajaran jarak jauh bagi dosen dan mahasiswa. Adapun tata cara untuk menggunakan aplikasi/media zoom ini lebih sederhana dan tergolong cukup mudah karena dapat digunakan melalui ponsel maupun pada komputer atau PC. Selain itu, terdapat beberapa kelebihan saat menggunakan aplikasi zoom antara lain adalah zoom dapat di-download secara gratis dan memungkinkan menggunakannya sampai 100 partisipan, dapat menjadwalkan pembelajaran, dapat merekam dan menyimpan video saat pembelajaran berlangsung, dan zoom dapat bekerja pada perangkat 
Android, Ios, Windows, dan Mac Virtual Background yang bisa diganti. ${ }^{28}$ Ditambahkan Abu Shadat Muhammad Sayem, dkk., yang menyatakan bahwa "Online support tools such as Zoom allow students and academics to connect through virtual tutorials from any convenient location, which is an effective use of technology to improve student engagement and their success rate while minimising the inconvenience of after-hours commitments for academics". ${ }^{29}$ Pernyataan tersebut dapat dimaknai bahwa alat dukungan online seperti zoom memungkinkan siswa dan akademisi untuk terhubung melalui tutorial virtual dari lokasi mana pun yang nyaman, yang merupakan penggunaan teknologi yang efektif untuk meningkatkan keterlibatan siswa dan tingkat keberhasilan mereka sambil meminimalkan ketidaknyamanan komitmen setelah jam kerja bagi akademisi.

Berdasarkan Tabel 2 di atas diperoleh informasi bahwa pada kategori sangat baik dengan interval 86-94 memiliki frekuensi 27 dan persentase 14,67\%, artinya bahwa sebanyak 27 responden dari 184 yang mengisi angket memiliki motivasi belajar yang sangat baik. Selanjutnya, pada kategori baik dengan interval 77-85 memiliki frekunsi 51 dan persentase 27,72\%, artinya bahwa sebanyak 51 responden dari 184 yang mengisi angket memiliki motivasi belajar yang baik. Selain itu, pada kategori cukup baik dengan interval 68-76 memiliki frekuensi 65 dan persentase 35,33\%, artinya bahwa sebanyak 65 responden dari 184 yang mengisi angket memiliki motivasi belajar yang cukup baik. Kemudian, pada kategori tidak baik dengan interval 59-67 memiliki frekuensi 41 dan persentase $22,28 \%$, artinya bahwa sebanyak 41 responden dari 184 yang mengisi angket memiliki motivasi belajar yang tidak baik. Persentase tertinggi skor angket motivasi belajar pada pembelajaran fikih Mahasiswa Jurusan Syariah Semester V Prodi Perbandingan Mazhab STIBA Makassar adalah 35,33\% dengan frekuensi 65 dan berada pada kategori cukup baik. Berdasarkan hasil analisis diperoleh informasi bahwa skor perolehan terendah dari angket motivasi belajar adalah 59, skor perolehan tertinggi dari angket motivasi belajar adalah 93. Nilai rata-rata diperoleh 75,09 dengan standar deviasi 8,34. Hal tersebut dapat dimaknai bahwa motivasi belajar pada pembelajaran fikih Mahasiswa Jurusan Syariah Semester V Prodi Perbandingan Mazhab STIBA Makassar cukup baik. Hal ini didasarkan pada hasil pengisian angket motivasi belajar oleh responden yang pada umumnya mereka menyatakan sangat senang ketika dosen menampilkan powerpoint untuk menjelaskan materi kuliah fikih melalui zoom.

Selain itu, berdasarkan jawaban responden diketahui bahwa umumnya responden cukup senang belajar menggunakan media berbasis video seperti zoom, tidak menunda dalam mengerjakan tugas mata kuliah fikih, berusaha untuk mendapatkan nilai terbaik dengan memerhatikan materi pada saat pembelajaran fikih berlangsung. Motivasi memegang peranan penting dalam keberhasilan seseorang mencapai tujuannya. Mc. Donald menyatakan bahwa motivasi merupakan perubahan energi dalam diri pribadi seseorang yang ditandai dengan timbulnya perasaan reaksi

\footnotetext{
${ }^{28}$ Junita Monica and Dini Fitriawati, "Efektivitas Penggunaan Aplikasi Zoom Sebagai Media Pembelajaran Online Pada Mahasiswa Saat Pandemi Covid-19," Jurnal Communio: Jurnal Jurusan Ilmu Komunikasi 9, no. 2 (2020): 1630-1640.

${ }^{29}$ Abu Shadat Muhammad Sayem et al., "Effective Use of Zoom Technology and Instructional Videos to Improve Engagement and Success of Distance Students in Engineering," in 28th Annual Conference of the Australasian Association for Engineering Education (AAEE 2017), 2017, 926.
} 
untuk mencapai tujuan. ${ }^{30}$ Motivasi mahasiswa dalam belajar membuat mereka melakukan berbagai upaya untuk mencapai hasil belajar yang maksimal. Temuan penelitian memberikan gambaran bahwa motivasi belajar merupakan salah satu hal yang patut mendapat perhatian khusus dari pendidik dan peserta didik dalam proses pembelajaran.

Berdasarkan Tabel 3 di atas atas diperoleh informasi bahwa pada kategori tinggi dengan interval 58-90 memiliki frekuensi 100 dengan persentase 54,35\%, artinya bahwa sebanyak 100 responden dari 184 yang menjawab tes memeroleh nilai dengan kategori tinggi. Selanjutnya, pada kategori rendah dengan interval 25-57 memiliki frekuensi 84 dengan persentase $45,65 \%$, artinya bahwa sebanyak 84 responden dari 184 yang menjawab tes memeroleh nilai dengan kategori rendah. Persentase tertinggi skor tes hasil belajar pada pembelajaran fikih Mahasiswa Jurusan Syariah Semester V Prodi Perbandingan Mazhab STIBA Makassar adalah 54,35\% dengan frekuensi 100 dan berada pada kategori tinggi. Berdasarkan hasil analisis (selengkapnya dapat dilihat pada lampiran) diperoleh informasi bahwa skor perolehan terendah dari tes hasil belajar adalah 25, skor perolehan tertinggi dari tes hasil belajar adalah 90. Nilai rata-rata diperoleh 59,41 dengan standar deviasi 17,39. Hal tersebut dapat dimaknai bahwa hasil belajar pada pembelajaran fikih Mahasiswa Jurusan Syariah Semester V Prodi Perbandingan Mazhab STIBA Makassar tinggi. Hasil belajar merupakan gambaran keberhasilan seseorang setelah melakukan rangkaian proses pembelajaran yang diperoleh melalui evaluasi belajar. Hal ini senada dengan yang dikemukakan A. Muri Yusuf bahwa hasil belajar merupakan wujud pencapaian peserta didik sekaligus merupakan lambang keberhasilan pendidik dalam membelajarkan peserta didik. ${ }^{31}$ Hasil belajar merupakan salah satu komponen yang penting dalam pembelajaran karena hasil belajar merupakan tolak ukur keberhasilan suatu proses pembelajaran. Selain itu, melalui hasil belajar dapat diketahui keberhasilan atau kekurangan proses pembelajaran yang telah berlangsung.

Sementara, hasil analisis statistik inferensial dapat diuraiakan sebagai berikut:

Hasil uji normalitas data penggunan media pembelajaran zoom, motivasi belajar mahasiswa, dan hasil belajar fikih diperoleh nilai sig. berturut-turut 0,200 ; 0,098; dan 0,067. Berdasarkan kriteria pengujian sig. $\geq \alpha(\alpha=0,05)$, dengan demikian dapat dikatakan bahwa data penggunan media pembelajaran zoom, motivasi belajar, dan hasil belajar fikih berasal dari populasi berdistribusi normal. Hasil uji linearitas linearitas antara hasil belajar fikih $(\mathrm{Y})$ atas penggunaan media pembelajaran zoom $\left(\mathrm{X}_{1}\right)$ adalah 0,077. Berdasarkan kriteria pengujian, sig. $\geq \alpha(0,077 \geq 0,05)$, sehingga dapat dikatakan bahwa data hasil belajar fikih (Y) atas penggunaan media pembelajaran zoom $\left(\mathrm{X}_{1}\right)$ adalah linear atau berupa garis linear/lurus. Sedangkan nilai sig. pengujian linearitas antara hasil belajar fikih (Y) atas motivasi belajar mahasiswa $\left(\mathrm{X}_{2}\right)$ adalah 0,783 . Berdasarkan kriteria pengujian, sig. $\geq \alpha(0,783 \geq 0,05)$, sehingga dapat dikatakan bahwa data hasil belajar fikih $(\mathrm{Y})$ atas motivasi belajar mahasiswa $\left(\mathrm{X}_{2}\right)$ adalah linear atau berupa garis linear/lurus. Nilai $r$ pengujian korelasi antara variabel penggunaan media pembelajaran zoom $\left(\mathrm{X}_{1}\right)$ dan variabel hasil belajar fikih (Y) adalah $r_{x 1 y}=0,284$. Berdasarkan pedoman yang diuraikan, nilai $\boldsymbol{r}_{\boldsymbol{x} \mathbf{1} y}>0$, sehingga dapat

\footnotetext{
${ }^{30}$ Oemar Hamalik, Proses Belajar Mengajar. (Jakarta: Bumi Aksara, 2012), h. 158.

${ }^{31}$ A Muri Yusuf, Asesmen Dan Evaluasi Pendidikan (Prenada Media, 2017). h. 181.
} 
dikatakan bahwa telah terjadi hubungan yang linear positif antara variabel penggunaan media pembelajaran zoom $\left(\mathrm{X}_{1}\right)$ dan variabel hasil belajar fikih $(\mathrm{Y})$. Sedangkan keeratan hubungan/korelasi antara variabel penggunaan media pembelajaran zoom $\left(\mathrm{X}_{1}\right)$ dan variabel hasil belajar fikih $(\mathrm{Y})$ yakni memiliki korelasi yang lemah tapi pasti karena berdasarkan pedoman yang diuraikan, nilai $r_{x l y}=0,284$ berada pada interval $0,20<r \leq 0,40$ yang bermakna korelasi yang lemah tapi pasti. Sedangkan, nilai $r$ pengujian korelasi antara variabel motivasi belajar mahasiswa $\left(\mathrm{X}_{2}\right)$ dan variabel hasil belajar fikih (Y) adalah $r_{x 2 y}=0,176$. Berdasarkan pedoman yang diuraikan, nilai $r_{x 2 y}>0$, sehingga dapat dikatakan bahwa telah terjadi hubungan yang linear positif antara variabel motivasi belajar mahasiswa $\left(\mathrm{X}_{2}\right)$ dan variabel hasil belajar fikih $(\mathrm{Y})$. Sedangkan keeratan hubungan/korelasi antara variabel motivasi belajar mahasiswa $\left(\mathrm{X}_{2}\right)$ dan variabel hasil belajar fikih $(\mathrm{Y})$ yakni memiliki korelasi yang sangat lemah karena berdasarkan pedoman yang diuraikan, nilai $r_{x 2 y}=0,176$ berada pada interval $0,00<r \leq 0,20$ yang bermakna korelasi yang sangat lemah.

Hasil uji hipotesis pengaruh penggunaan media pembelajaran zoom $\left(\mathrm{X}_{1}\right)$ terhadap hasil belajar fikih (Y), diperoleh nilai sig. $=0,000$. Berdasarkan kriteria pengujian hipotesis, sig. $<\alpha(0,000<0,05)$ sehingga $\mathrm{H}_{0}$ ditolak. Dengan demikian, dapat dikatakan bahwa ada pengaruh penggunaan media pembelajaran zoom terhadap hasil belajar fikih pada Mahasiswa Jurusan Syariah Semester V Prodi Perbandingan Mazhab Sekolah Tinggi Ilmu Bahasa Arab (STIBA) Makassar. Nilai koefisien korelasi $(R)$ antara variabel penggunaan media pembelajaran zoom dengan variabel hasil belajar fikih diperoleh 0,284 , artinya bahwa dalam penelitian ini $28,4 \%$ variabel hasil belajar fikih dipengaruhi oleh variabel penggunaan media pembelajaran zoom dan termasuk kategori pengaruh yang lemah tapi pasti. Temuan penelitian ini sejalan dengan hasil penelitian yang dilakukan oleh Ismail Akbar Brahma yang menyimpulkan bahwa zoom menjadi alternatif media pembelajaran online di tengah pandemi Covid-19. Mahasiswa dan dosen tetap menjalankan kegiatan pembelajaran secara jarak jauh. Dosen dan mahasiswa dapat melakukan video konferensi melalui zoom yang dijadikan sarana berkomunikasi dalam pembelajaran secara online. ${ }^{32}$ Sejalan dengan hal tersebut, Suardi M menyatakan bahwa:

"From the research process carried out, it was found that in the cognitive aspect, the transfer of knowledge continued as usual, the same as the face-toface learning process in class and even had advantages because the learning process was relaxed. In the affective aspect, students get good role models, especially in terms of the consistency of lecturers who continue to teach even though they are unable to attend the classroom face-to-face, and on the psychomotor aspect, the use of ZOOM Cloud Meetings is also effective because students who are actually prospective teachers can learn a new skill. in teaching as well as new knowledge in using each android productively. So

${ }^{32}$ Ismail Akbar Brahma, "Penggunaan Zoom Sebagai Pembelajaran Berbasis Online Dalam Mata Kuliah Sosiologi Dan Antropologi Pada Mahasiswa PPKN Di STKIP Kusumanegara Jakarta," Aksara: Jurnal Ilmu Pendidikan Nonformal 6, no. 2 (2020): 97-102. 
it can be concluded that the use of the ZOOM Cloud Meetings application is very effective in the learning process". ${ }^{33}$

Hasil penelitian Suardi M tersebut, ditemukan bahwa pada aspek kognitif, transfer pengetahuan berlangsung seperti biasa, sama seperti proses pembelajaran tatap muka di kelas bahkan memiliki kelebihan karena proses pembelajarannya santai. Sedangkan pada aspek afektif mahasiswa mendapatkan suri tauladan yang baik terutama dalam hal konsistensi dosen tetap mengajar meskipun berhalangan hadir di kelas secara tatap muka, dan pada aspek psikomotorik, pemanfaatan Zoom Cloud Meetings juga efektif karena mahasiswa yang sebenarnya calon guru dapat mempelajari keterampilan baru dalam mengajar serta ilmu baru dalam menggunakan setiap android secara produktif, sehingga dapat disimpulkan bahwa penggunaan aplikasi ZOOM Cloud Meetings sangat efektif dalam proses pembelajaran.

Hasil uji hipotesis pengaruh motivasi belajar mahasiswa $\left(\mathrm{X}_{2}\right)$ terhadap hasil belajar fikih (Y), diperoleh nilai sig. $=0,017$. Berdasarkan kriteria pengujian hipotesis, sig. $<\alpha(0,017<0,05)$ sehingga $\mathrm{H}_{0}$ ditolak. Dengan demikian, dapat dikatakan bahwa ada pengaruh motivasi belajar terhadap hasil belajar fikih pada Mahasiswa Jurusan Syariah Semester V Prodi Perbandingan Mazhab Sekolah Tinggi Ilmu Bahasa Arab (STIBA) Makassar. Nilai keofisien korelasi $(R)$ antara variabel motivasi belajar dengan hasil belajar fikih diperoleh 0,176 , artinya bahwa dalam penelitian ini 17,6\% variabel hasil belajar fikih dipengaruhi oleh variabel motivasi belajar dan termasuk pengaruh yang sangat lemah. Hasil penelitian ini menunjukkan bahwa motivasi belajar berpengaruh terhadap hasil belajar mahasiswa. Hal ini sejalan dengan hasil penelitian Sofwan Adiputra dan Mujiyati (2017) yang menyimpulkan bahwa terdapat hubungan antara motivasi siswa terhadap prestasi siswa. ${ }^{34}$ Hasil penelitian ini juga sejalan dengan penelitian Anni Attika Robbi, dkk., yang menyimpulkan bahwa "learning motivation has a significant effect on student achievement", artinya motivasi belajar berpengaruh signifikan terhadap prestasi belajar siswa. ${ }^{35}$

Hasil uji hipotesis pengaruh penggunaan media pembelajaran zoom $\left(\mathrm{X}_{1}\right)$ dan motivasi belajar mahasiswa $\left(\mathrm{X}_{2}\right)$ secara bersama terhadap variabel hasil belajar fikih $(\mathrm{Y})$, diperoleh nilai sig. $=0,000$. Berdasarkan kriteria pengujian hipotesis, sig. $<\alpha$ $(0,000<0,05)$ sehingga $\mathrm{H}_{0}$ ditolak. Dengan demikian, dapat dikatakan bahwa ada pengaruh penggunaan media pembelajaran zoom dan motivasi belajar secara bersama terhadap hasil belajar fikih pada Mahasiswa Jurusan Syariah Semester V Prodi Perbandingan Mazhab Sekolah Tinggi Ilmu Bahasa Arab (STIBA) Makassar. Hasil penelitian ini menunjukkan bahwa zoom cukup baik digunakan sebagai media pembelajaran jarak jauh. Hal ini sejalan dengan temuan penelitian Trisna Helda dan M. Zaim (2021) yang menyimpulkan bahwa "the use of the Zoom Meeting application

${ }^{33}$ M Suardi, "The Effectiveness of Using the ZOOM Cloud Meetings Application in the Learning Process," in International Conference on Science and Advanced Technology (ICSAT), 2020. p. 590602.

${ }^{34}$ Sofwan Adiputra and Mujiyati Mujiyati, "Motivasi Dan Prestasi Belajar Siswa Di Indonesia: Kajian Meta-Analisis,” Konselor 6, no. 4 (2017): 150-157.

${ }^{35}$ Anni Attika Robbi, Gusnardi Gusnardi, and Sumarno Sumarno, "Analysis of the Effect of Learning Motivation on Learning Achievement," Journal of Educational Sciences 4, no. 1 (2020): 106115 . 
is effective in online learning media and can be used as a learning application during the Covid-19 pandemic". ${ }^{36}$ Artinya, penggunaan aplikasi Zoom Meeting efektif sebagai media pembelajaran online dan dapat digunakan sebagai aplikasi pembelajaran di masa pandemi Covid-19. Selain itu, hasil penelitian ini juga sejalan dengan hasil penelitian yang dilakukan oleh Dian Permanasari Widyaningrum yang menyimpulkan bahwa penerapan zoom meeting pada pembelajaran jarak jauh berbasis E-Learning mempunyai pengaruh signifikan dalam meningkatkan kemampuan kognitif peserta didik. ${ }^{37}$

Selain itu, hasil penelitian ini sejalan juga dengan hasil penelitian Sicat yang menunjukkan bahwa fleksibilitas waktu, lokasi, dan metode pembelajaran online memengaruhi kepuasan belajar peserta didik terhadap pembelajaran. Belajar dari rumah membuat mereka tidak merasakan tekanan sebaya yang biasa mereka rasakan ketika belajar bersama teman yang dilaksanakan secara tatap muka. Selain itu pembelajaran secara online menghilangkan perasaan canggung sehingga peserta didik dapat mengekspresikan pikirannya dan bertanya secara bebas. Pembelajaran jarak jauh secara online juga mampu menumbuhkan kemandirian belajar peserta didik. ${ }^{38}$ Hasil penelitian ini juga sejalan dengan hasil penelitian Sugiyanto, dkk. yang menyimpulkan "intrinsic motivation improved the learning outcomes for vocational students. Curiosity was identified as the most important aspect of learning motivation as it had the greatest influence on improving learning outcomes". Artinya, motivasi intrinsik meningkatkan hasil belajar mahasiswa. Rasa ingin tahu diidentifikasi sebagai aspek yang paling penting dari motivasi belajar karena memiliki pengaruh terbesar pada peningkatan hasil belajar. ${ }^{39}$

Hasil penelitian juga sejalan dengan hasil penelitian Ming-Hung Lin, dkk., menyimpulkan bahwa:

"(1) Digital learning presents better positive effects on learning motivation than traditional teaching does, (2) digital learning shows better positive effects on learning outcome than traditional teaching does, (3) learning motivation reveals significantly positive effects on learning effect in learning outcome, and (4) learning motivation appears remarkably positive effects on learning gain in learning outcome. "40

Hasil penelitian Ming-Hung Lin, dkk., tersebut menyimpulkan bahwa pembelajaran digital memberikan pengaruh positif yang lebih baik pada motivasi

\footnotetext{
${ }^{36}$ Trisna Helda and M Zaim, "Effectiveness of The Zoom Meeting Applications In Micro Teaching Lectures In The Pandemictime COVID-19," in English Language and Literature International Conference (ELLiC) Proceedings, vol. 4, 2021, 128-135.

${ }^{37}$ Dian Permanasari Widyaningrum, "The Effect of Zoom Meeting On E-Learning Based Remote Learning In Improving Student Cognitive Ability," Mataazir: Jurnal Administrasi Dan Manajemen Pendidikan 1, No. 2 (2020): 62-77.

${ }^{38}$ Alvin S Sicat and M A Ed, "Enhancing College Students' Proficiency in Business Writing via Schoology," International Journal of Education and Research 3, no. 1 (2015): 159-178.

${ }^{39}$ Sugiyanto Sugiyanto, Badaruddin Mohammad, and Herpratiwi Herpratiwi, "The Influence of Learning Motivation on the Learning Outcomes of Vocational Students at Lampung University," International Journal of Advanced Science and Technology 29, no. 05 (2020): 133-140.

${ }^{40}$ Ming-Hung Lin and Huang-g Chen, "A Study of the Effects of Digital Learning on Learning Motivation and Learning Outcome," Eurasia Journal of Mathematics, Science and Technology Education 13, no. 7 (2017): 3553-3564.
} 
belajar dari pada pembelajaran tradisional, pembelajaran digital menunjukkan pengaruh positif yang lebih baik pada hasil belajar dari pada pembelajaran tradisional, motivasi belajar menunjukkan pengaruh positif yang signifikan terhadap hasil belajar, dan motivasi belajar sangat berpengaruh positif terhadap hasil belajar.

\section{KESIMPULAN}

Dari hasil analisis dan pembahasan di atas, dapat disimpulkan bahwa:

1. Penggunaan media pembelajaran zoom pada pembelajaran fikih Mahasiswa Jurusan Syariah Semester V Prodi Perbandingan Mazhab STIBA Makassar berada pada kategori cukup baik. Jumlah responden 184 orang, skor tertinggi diperoleh 93, skor terendah diperoleh 31, dan rata-rata skor 60,4.

2. Motivasi belajar Mahasiswa Jurusan Syariah Semester V Prodi Perbandingan Mazhab STIBA Makassar berada pada kategori cukup baik. Jumlah responden 184 orang, skor tertinggi diperoleh 93, skor terendah diperoleh 59, dan rata-rata skor 75,09 .

3. Hasil belajar fikih Mahasiswa Jurusan Syariah Semester V Prodi Perbandingan Mazhab STIBA Makassar berada pada kategori tinggi. Jumlah responden 184 orang, skor tertinggi diperoleh 90, skor terendah diperoleh 25, dan rata-rata skor 59,41 .

4. Terdapat pengaruh penggunaan media pembelajaran zoom terhadap hasil belajar fikih pada Mahasiswa Jurusan Syariah Semester V Prodi Perbandingan Mazhab STIBA Makassar sebesar 28,4\%, termasuk kategori yang lemah tapi pasti.

5. Terdapat pengaruh motivasi belajar terhadap hasil belajar fikih pada Mahasiswa Jurusan Syariah Semester V Prodi Perbandingan Mazhab STIBA Makassar sebesar $17,6 \%$, termasuk kategori yang sangat lemah.

6. Terdapat pengaruh penggunaan media pembelajaran zoom dan motivasi belajar secara bersama terhadap hasil belajar fikih pada Mahasiswa Jurusan Syariah Semester V Prodi Perbandingan Mazhab STIBA Makassar sebesar 8,8\%, termasuk kategori yang sangat lemah.

\section{DAFTAR PUSTAKA}

Adiputra, Sofwan, and Mujiyati Mujiyati. "Motivasi Dan Prestasi Belajar Siswa Di Indonesia: Kajian Meta-Analisis." Konselor 6, no. 4 (2017): 150-57.

Asiani, Ani, and Jonet Ariyanto Nugroho. "Penerapan Model Attention, Relevance, Confidence, And Satisfaction (Arcs) Untuk Meningkatkan Motivasi Dan Hasil Belajar Siswa Kelas X Pemasaran 1 Smk Negeri 1 Surakarta Tahun Pelajaran 2016/2017." Jurnal Pendidikan Bisnis Dan Ekonomi 3, no. 1 (2017).

Brahma, Ismail Akbar. "Penggunaan Zoom Sebagai Pembelajaran Berbasis Online Dalam Mata Kuliah Sosiologi Dan Antropologi Pada Mahasiswa PPKN Di STKIP Kusumanegara Jakarta.” Aksara: Jurnal Ilmu Pendidikan Nonformal 6, no. 2 (2020): 97-102.

Cahyani, Adhetya, Iin Diah Listiana, and Sari Puteri Deta Larasati. "Motivasi Belajar Siswa SMA Pada Pembelajaran Daring Di Masa Pandemi Covid-19." IQ (Ilmu Al-Qur'an): Jurnal Pendidikan Islam 3, no. 01 (2020): 123-40.

Chusyairi, Ahmad, and Sahla Sabira. "Pelatihan Pembuatan Konten Pendidikan Pada YouTube Menggunakan Zoom Dan Editing Video Filmora." JILPENMAS (Jurnal Ilmiah Pengabdian Masyarakat) 1, no. 01 (2020): 55-65. 
Dimyati, Mudjiono. "Belajar Dan Pembelajaran.” Jakarta: Rineka Cipta, 2006.

Engkos, Ridwan, and Achmad Kuncoro. "Cara Menggunakan Dan Memaknai Path Analysis.” Bandung: Alfabeta, 2012.

Hamzah, B Uno. "Teori Motivasi Dan Pengukurannya.” Jakarta: Bumi Aksara, 2008. Haqien, Danin, and Aqiilah Afiifadiyah Rahman. "Pemanfaatan Zoom Meeting Untuk Proses Pembelajaran Pada Masa Pandemi Covid-19." SAP (Susunan Artikel Pendidikan) 5, no. 1 (2020).

Harun, Muhamad. "Evaluasi Kualitas Perangkat Lunak Pada Aplikasi Zoom Cloud Meetings Untuk Pembelajaran Elearning." Jurnal Akrab Juara 5, no. 3 (2020): $102-12$.

Helda, Trisna, and M Zaim. "Effectiveness of The Zoom Meeting Applications In Micro Teaching Lectures In The Pandemictime COVID-19." In English Language and Literature International Conference (ELLiC) Proceedings, 4:12835, 2021.

Ismawati, Dwi, and Iis Prasetyo. "Efektivitas Pembelajaran Menggunakan Video Zoom Cloud Meeting Pada Anak Usia Dini Era Pandemi Covid-19." Jurnal Obsesi: Jurnal Pendidikan Anak Usia Dini 5, no. 1 (2020): 665-75.

Jamaris, Martini. "Orientasi Baru Dalam Psikologi Pendidikan." Bogor: Ghalia Indonesia, 2013.

Jamil, Mekka Madaina. “Optimalisasi Model ARCS Dalam Pembelajaran Saintifik Untuk Meningkatkan Motivasi Belajar Peserta Didik Pada Peminatan Mata Pelajaran Geografi Di Kelas Matematika Ilmu Alam." IJIS Edu: Indonesian Journal of Integrated Science Education 1, no. 1 (2019): 7-24.

Lin, Ming-Hung, and Huang-g Chen. "A Study of the Effects of Digital Learning on Learning Motivation and Learning Outcome." Eurasia Journal of Mathematics, Science and Technology Education 13, no. 7 (2017): 3553-64.

Mappeasse, Muh Yusuf. "Pengaruh Cara Dan Motivasi Belajar Terhadap Hasil Belajar Programmable Logic Controller (PLC) Siswa Kelas III Jurusan Listrik SMK Negeri 5 Makassar." Jurnal Medtek 1, no. 2 (2009): 1-6.

Monica, Junita, and Dini Fitriawati. "Efektivitas Penggunaan Aplikasi Zoom Sebagai Media Pembelajaran Online Pada Mahasiswa Saat Pandemi Covid-19." Jurnal Communio: Jurnal Jurusan Ilmu Komunikasi 9, no. 2 (2020): 1630-40.

Oemar Hamalik. Proses Belajar Mengajar. Jakarta: Bumi Aksara, 2012.

Purwanto. Evaluasi Hasil Belajar. 3rd ed. Yogyakarta: Pustaka Pelajar, 2011.

Rifa'i Rc, Achmad, and Catharina Tri Anni. "Psikologi Pendidikan." Semarang: Pusat Pengembangan MKU \&MKDK Universitas Negeri Semarang, 2011.

Robbi, Anni Attika, Gusnardi Gusnardi, and Sumarno Sumarno. "Analysis of the Effect of Learning Motivation on Learning Achievement." Journal of Educational Sciences 4, no. 1 (2020): 106-15.

Saat, Sulaiman, and Sitti Mania. "Pengantar Metodologi Penelitian: Panduan Bagi Peneliti Pemula," 2020.

Sadikin, Ali, and Afreni Hamidah. "Pembelajaran Daring Di Tengah Wabah Covid-19 (Online Learning in the Middle of the Covid-19 Pandemic)." Biodik 6, no. 2 (2020): 214-24.

Sayem, Abu Shadat Muhammad, Benjamin Taylor, Mitchell McClanachan, and Umme Mumtahina. "Effective Use of Zoom Technology and Instructional 
Videos to Improve Engagement and Success of Distance Students in Engineering." In 28th Annual Conference of the Australasian Association for Engineering Education (AAEE 2017), 926, 2017.

Sicat, Alvin S, and M A Ed. "Enhancing College Students' Proficiency in Business Writing via Schoology." International Journal of Education and Research 3, no. 1 (2015): 159-78.

Siregar, Syofian. "Statistik Parametrik Untuk Penelitian Kuantitatif," 2014.

Slameto. Belajar Dan Faktor-Faktor Yang Mempengaruhinya. Jakarta: Rineka Cipta, 2010.

Suardi, M. "The Effectiveness of Using the ZOOM Cloud Meetings Application in the Learning Process." In International Conference on Science and Advanced Technology (ICSAT), 2020.

Sugiyanto, Sugiyanto, Badaruddin Mohammad, and Herpratiwi Herpratiwi. "The Influence of Learning Motivation on the Learning Outcomes of Vocational Students at Lampung University." International Journal of Advanced Science and Technology 29, no. 05 (2020): 133-40.

Sumantri, Mohamad Syarif. "Strategi Pembelajaran Teori Dan Praktik Di Tingkat Pendidikan Dasar." Jakarta: Rajawali Pers, 2015.

Syah, Muhibbin. Psikologi Pendidikan Dengan Pendekatan Baru. Bandung: Remaja Rosdakarya, 2010.

Widyaningrum, Dian Permanasari. "The Effect of Zoom Meeting On E-Learning Based Remote Learning In Improving Student Cognitive Ability." MATAAZIR: Jurnal Administrasi Dan Manajemen Pendidikan 1, no. 2 (2020): 62-77.

Winard. Motivasi Dan Permotivasian Dalam Manajemen. Jakarta: Raja Grafindo Persada, 2011.

Yuliana, Yuliana. "Corona Virus Diseases (Covid-19): Sebuah Tinjauan Literatur." Wellness And Healthy Magazine 2, no. 1 (2020): 187-92.

Yulianto, Eko, Putri Dwi Cahyani, and Sofia Silvianita. "Perbandingan Kehadiran Sosial Dalam Pembelajaran Daring Menggunakan Whatsapp Groupdan Webinar Zoom Berdasarkan Sudut Pandang Pembelajar Pada Masa Pandemic COVID19.” Jurnal Riset Teknologi Dan Inovasi Pendidikan (JARTIKA) 3, no. 2 (2020): 331-341.

Yusuf, A Muri. Asesmen Dan Evaluasi Pendidikan. Prenada Media, 2017. 